\title{
Determination and pharmacokinetics study of oxyclozanide suspension in cattle by LC- MS/MS
}

Jili Zhang ${ }^{1,2,3}$, Yubin Bai ${ }^{1,2,3}$, Bing Li $i^{1,2,3}$, Xuzheng Zhou ${ }^{1,2,3}$, Hongfei $\mathrm{Si}^{1,2,3}$ and Jiyu Zhang ${ }^{1,2,3^{*}}$ (D)

\begin{abstract}
Background: Oxyclozanide is an anthelmintic drug that is widely used to treat fasciolosis. However, the pharmacokinetics of oxyclozanide in cattle are not yet clearly understood. The present study was designed to develop a sensitive method to determine oxyclozanide levels in cattle plasma using high-performance liquid chromatography-tandem mass spectrometry (HPLC-MS/MS) and to study its pharmacokinetics for application in cattle.
\end{abstract}

Results: A simple and rapid HPLC-MS/MS analytical method was established and validated to quantify oxyclozanide levels in cattle plasma using niclosamide as the internal standard (IS) in negative ion mode. Chromatographic separation of the analytes was achieved using a $C_{18}$ analytical column $(75 \times 4.6 \mathrm{~mm}, 2.7 \mu \mathrm{m})$ at $30^{\circ} \mathrm{C}$. The mobile phase comprised $0.01 \% \mathrm{v} / \mathrm{v}$ acetic acid ( $\mathrm{HOAc}$ ) diluted in water:acetonitrile (MeCN) $(90: 10 \% \mathrm{v} / \mathrm{v})$ and $5 \mathrm{mM}$ ammonium formate in methanol (MeOH):MeCN (75:25, v/v) at a 10:90 ratio ( $/ / \mathrm{v})$ and was delivered at a flow rate of $0.4 \mathrm{~mL} \mathrm{~min}^{-1}$. A good linear response across the concentration range of $0.02048-25.600 \mu \mathrm{g} / \mathrm{mL}$ was achieved $\left(r^{2}=0.994\right)$. The method was validated with respect to linearity, matrix effect, accuracy, precision, recovery and stability. The lower limit of quantification (LLOQ) was $0.020 \mu \mathrm{g} / \mathrm{mL}$, and the extraction recovery was $>98 \%$ for oxyclozanide. The inter- and intra-day accuracy and precision of the method showed the relative standard deviation (RSD) less than $10 \%$. The method was successfully applied to an assessment of the pharmacokinetics of oxyclozanide in cattle plasma. In healthy cattle, a single oral dose of an oxyclozanide suspension followed the onecompartment model, with a half-life $\left(T_{1 / 2}\right)$ of $64.40 \pm 30.18 \mathrm{~h}$, a plasma clearance rate (CL/F) of $11.426 \pm 2.442$ $\mathrm{mL} / \mathrm{h} / \mathrm{kg}$, and an average area under the curve (AUC) of $965.608 \pm 220.097 \mathrm{~h} * \mathrm{\mu g} / \mathrm{mL}$. The peak concentration $\left(C_{\max }\right)$ was $15.870 \pm 2.855 \mu \mathrm{g} / \mathrm{mL}$, which occurred at a peak time $\left(T_{\max }\right)=22.032 \pm 3.343 \mathrm{~h}$.

Conclusions: A reliable, accurate HPLC-MS/MS analytical method was established in our study and successful applied to study the pharmacokinetics of oxyclozanide in cattle plasma. These results will be useful for further evaluations of the pharmacokinetic properties of oxyclozanide or for monitoring therapeutic drugs in animals.

Keywords: Oxyclozanide, Niclosamide, LC-MS/MS, Cattle plasma, Pharmacokinetics

\footnotetext{
* Correspondence: zhangjiyu@caas.cn

'Key Laboratory of Veterinary Pharmaceutical Development, Lanzhou Institute of Husbandry and Pharmaceutical Sciences, Chinese Academy of Agricultural Sciences, Ministry of Agriculture, Lanzhou, Gansu Province 730050, People's Republic of China

${ }^{2}$ Key Laboratory of New Animal Drug Project of Gansu Province, Lanzhou, Gansu Province, People's Republic of China

Full list of author information is available at the end of the article
}

\section{Background}

Fasciola hepatica is an economically important parasite that causes the neglected tropical disease of ruminants known as 'fasciolosis' and affects agriculturally important ruminant animals [1-3]. It has a composite life cycle that involves a snail as an intermediate host before being transferred to definite hosts, namely, humans and other herbivorous mammals, through contaminated water or green vegetables [1, 4]. Fasciolosis is geographically widely dispersed in Africa, Asia, Europe, the Americas and Oceania, as well as some

(c) The Author(s). 2019 Open Access This article is distributed under the terms of the Creative Commons Attribution 4.0 International License (http://creativecommons.org/licenses/by/4.0/), which permits unrestricted use, distribution, and 
temperate countries and regions, and causes significant financial losses $[4,5]$. Currently, control of fasciolosis in animals is achieved through the use of flukicidal drugs. However, due to the complex life cycle of $F$. hepatica, a lack of monitoring of treatment efficiency, and frequent reports of flukicide resistance [6-8], fasciolosis control is difficult. Oxyclozanide (3, $3^{\prime}, 5,5^{\prime}, 6$ pentachloro-2'-hydroxy salicylanilide) is a salicylanilide anthelmintic drug that mainly acts by uncoupling oxidative phosphorylation [9]. As a broadspectrum anthelmintic drug, oxyclozanide has been widely used to treat infections caused by Fasciola gigantica, F. hepatica, Paramphistomum leydeni, and Calicophoron daubneyi, as well as other intestinal trematodes and gastrointestinal nematodes [10-13], and has not been reported to induce resistance. It also continues to be an important drug because of its efficacy against triclabendazoleresistant Fasciola species [14]. To date, no pharmaceutical formulation of oxyclozanide is available in China. A new pharmaceutical formulation of oxyclozanide suspension has been successfully prepared by Lanzhou Institute of Husbandry and Pharmaceutical Sciences to meet the clinical needs of veterinarians. This oxyclozanide suspension possesses good physical properties, good stability and dispersion, controllable quality and exerts remarkable therapeutic effects on $F$. hepatica infections [15]. However, the pharmacokinetic profile of the oxyclozanide suspension in cattle has never been measured.

In fact, despite the widespread use of oxyclozanide for many years, little information has been published on the pharmacokinetics of oxyclozanide in cattle plasma. Instead, some methods have recently been developed to detect oxyclozanide residues in dairy animals. For example, levels of oxyclozanide residues in milk have been measured using ultra-high-performance liquid chromatography-tandem mass spectrometry (UPLC-MS/MS) and liquid chromatography coupled with tandem mass spectrometry (LC-MS/MS) methods [16-18]. Meanwhile, the stability of oxyclozanide residues in beef during cooking has been analysed using a UPLC-MS/MS method [19]. Highperformance liquid chromatography-tandem mass spectrometry (HPLC-MS/MS) has also been applied to assess the levels of oxyclozanide residues in bovine kidney [20]. In addition, an LC method has been developed to determine oxyclozanide levels in pharmaceutical formulations [21]. An HPLC analytical method has been developed to compare the pharmacokinetics of oxyclozanide in goats and sheep [22].

The aim of this study was to establish a sensitive and reliable HPLC-MS/MS method to analyse the pharmacokinetics of oxyclozanide in cattle plasma and study its application through examination of the pharmacokinetics of this drug in cattle.

\section{Methods}

\section{Reagents and chemicals}

Standard oxyclozanide and niclosamide (Internal stander; IS) were provided by Dr. Ehrenstorfer from $\mathrm{GmbH}$ (Germany) (batch numbers C15793000 and C15510000, respectively) with a purity $>99 \%$. Analytical grade methanol $(\mathrm{MeOH})$, acetonitrile $(\mathrm{MeCN})$, acetic acid (HOAc), and ammonium formate were purchased from Fisher Chemical (Waltham, MA, USA). Water was purified through a Milli-Q Plus water system (Millipore Corporation, Bedford, MA, USA) before use. The oxyclozanide suspension (active ingredient oxyclozanide, 3.4\%; batch number 20170104) was supplied by the Lanzhou Institute of Husbandry and Pharmaceutical Sciences (Lanzhou, China).

\section{LC/MS/MS analysis}

The LC analysis was performed using an Agilent 1200 series instrument (Agilent Technologies, USA) containing two SL bin-pumps, an on-line degasser, a column oven and an autosampler. The analytes were separated using an Agilent Poroshell $120 \mathrm{SB}^{-\mathrm{C}_{18}}(75 \times 4.6 \mathrm{~mm}$, $2.7 \mu \mathrm{m})$; mobile phase A $(0.01 \% \mathrm{HOAc}$ in water:MeCN; $90: 10 \mathrm{v} / \mathrm{v})$ and mobile phase B $(5 \mathrm{mM}$ ammonium formate in $\mathrm{MeOH}: \mathrm{MeCN}(75: 25, \mathrm{v} / \mathrm{v})$ were used as the mobile phase at a ratio of 10:90 v/v. The mobile phase was filtered before use to prevent the entry of bubbles or impurities into the system and was delivered at a flow rate of $0.4 \mathrm{~mL} / \mathrm{min}$. The sample was injected at a volume of $5 \mu \mathrm{L}$ at $30^{\circ} \mathrm{C}$.

The mass spectroscopy analysis was performed using a G6410A triple-quadruple tandem mass spectrometer with electrospray ionization (ESI) (Agilent Technologies Inc., Santa Clara, CA, USA) in negative ion mode. The following MS/MS parameters were used: capillary voltage, $4 \mathrm{KV}$; source temperature, $330^{\circ} \mathrm{C}$; and nitrogen gas flow rate, $11 \mathrm{~L} / \mathrm{min}$. The optimized fragmentation voltages for oxyclozanide and niclosamide were $100 \mathrm{~V}$ and $90 \mathrm{~V}$, respectively, and the delta electron multiplier voltage was $400 \mathrm{~V}$. Data were collected in multiple reaction monitoring (MRM) mode using $[\mathrm{M}-\mathrm{H}]^{-}$ions for oxyclozanide and niclosamide (IS), with collision energies of 30 and $20 \mathrm{eV}$, respectively. Mass Hunter software (version B.01.04, Agilent Technologies Inc.) was used for system control, data acquisition, and data processing.

\section{Preparation of standard solutions}

For the standard stock solution of oxyclozanide, $100 \mathrm{mg}$ of oxyclozanide was placed into a $50 \mathrm{~mL}$ brown volumetric flask, after which methanol was added to produce a stock solution of $2000 \mu \mathrm{g} / \mathrm{mL}$ oxyclozanide. A series of working oxyclozanide solutions was prepared by diluting the standard stock solution with the mobile phase to 
obtain the following concentrations $(\mu \mathrm{g} / \mathrm{mL})$ : 1.024, 16.384, 32.768, 262.144, 655.360, 1024 and 1280.

For the IS solution, $1.000 \mathrm{mg}$ of niclosamide was placed in a $100 \mathrm{~mL}$ brown volumetric flask, to which methanol was added to produce a stock solution of $10.00 \mu \mathrm{g} / \mathrm{mL}$ niclosamide. Next, $1 \mathrm{~mL}$ of the niclosamide stock solution was mixed with the mobile phase in a $50 \mathrm{~mL}$ volumetric flask to produce a solution of $0.200 \mu \mathrm{g} / \mathrm{mL}$ niclosamide. All solutions were stored at $4{ }^{\circ} \mathrm{C}$ and brought to room temperature before use.

\section{Working solutions and sample preparation}

Plasma calibration standards with concentrations ranging from $0.02048-25.600 \mu \mathrm{g} / \mathrm{mL}$ were prepared by adding $10 \mu \mathrm{L}$ of each of the oxyclozanide standard solutions $(1.024-1280 \mu \mathrm{g} / \mathrm{mL})$ and $10 \mu \mathrm{L}$ of the niclosamide $(0.200 \mu \mathrm{g} / \mathrm{mL})$ IS solution to $500 \mu \mathrm{L}$ aliquots of blank plasma. Quality control (QC) samples were prepared in the same way at different oxyclozanide concentrations: $0.020 \mu \mathrm{g} / \mathrm{mL}$ (lower limit of quantification, LLOQ), $0.02048 \mu \mathrm{g} / \mathrm{mL}$ (QC-low), $12.7612 \mu \mathrm{g} / \mathrm{mL}$ (QC-med), and $25.600 \mu \mathrm{g} / \mathrm{mL}$ (QC-high). The calibration standards and QC samples were applied for method validation in the pharmacokinetic study.

Plasma aliquots $(500 \mu \mathrm{L})$ were spiked with $10 \mu \mathrm{L}$ of the niclosamide $(0.200 \mu \mathrm{g} / \mathrm{mL})$ IS solution in centrifuge tubes, after which acetonitrile $(1.5 \mathrm{~mL})$ was added. The sample was mixed by vortexing $(30 \mathrm{~s})$ and centrifuged at $3000 \times \mathrm{g}$ for $20 \mathrm{~min}$, and the supernatant was evaporated to dryness at $40^{\circ} \mathrm{C}$ with a vacuum concentration system (Rapid Vap ${ }^{\circ}$ Vertex Evaporator, Labconco, USA). The dry residue was reconstituted in $500 \mu \mathrm{L}$ of mobile phase and immediately subjected to vortexing for $20 \mathrm{~s}$, after which the solution was filtered through a $0.22 \mu \mathrm{m}$ Millipore filter and injected into the LC-MS/MS system.

\section{Method validation Selectivity and matrix effect}

Selectivity was examined by comparing the chromatograms of eight different batches of blank cattle plasma with those of corresponding plasma samples spiked with oxyclozanide and the IS to exclude the interfering peaks [23].

The matrix effect was evaluated by comparing the area response of post-extraction blank plasma samples spiked with oxyclozanide at three QC levels with the equivalent concentration standard solutions that were dried directly and reconstituted with the same mobile phase [24].

\section{$\angle L O Q$ and linearity}

The LLOQ and the lower limit of detection (LLOD) were determined as the concentrations that produced signal/noise ratioes of 10 and 3, respectively. For the linearity of this method, a calibration curve was generated with plasma standards containing different concentrations of oxyclozanide ranging from $0.02048-25.600 \mu \mathrm{g} /$ $\mathrm{mL}$. A calibration curve was constructed by plotting the peak area ratio of oxyclozanide/IS (y) vs the nominal concentration of oxyclozanide $(x)$ in the form of $y=a x+b$; the least square method was used for the linear regression analysis. A coefficient of correlation $\left(\mathrm{r}^{2}\right)$ of at least 0.99 was required to meet the criterion.

\section{Accuracy and precision}

The precision was determined as the relative standard deviation (RSD) of replicate measurements, and the accuracy was evaluated as the ratio of calculated vs. theoretical concentrations, as previously described [24]. The intra-day accuracy and precision of the HPLC/MS/MS method were determined by analysing QC concentrations $(0.02048 \mu \mathrm{g} / \mathrm{mL}, 12.7612 \mu \mathrm{g} / \mathrm{mL}$ and $25.600 \mu \mathrm{g} / \mathrm{mL})$ and the LLOD concentration in six replicates per concentration on the same day. Inter-day accuracy and precision were evaluated by analysing QC concentrations $(0.02048 \mu \mathrm{g} / \mathrm{mL}, 12.7612 \mu \mathrm{g} / \mathrm{mL}$ and $25.600 \mu \mathrm{g} / \mathrm{mL})$ and the LLOD concentration in six measurements of each concentration conducted over 3 days [25]. According to the $\mathrm{ICH}$ [26], the criterion for precision and accuracy was an RSD $\leq 15 \%$ for each concentration, except for the LLOQ $(\leq 20 \%)$.

\section{Recovery and stability}

Three concentrations of QC samples $(0.02048 \mu \mathrm{g} / \mathrm{mL}$, $12.7612 \mu \mathrm{g} / \mathrm{mL}$ and $25.600 \mu \mathrm{g} / \mathrm{mL}$ ) and a single concentration of IS $(0.004 \mu \mathrm{g} / \mathrm{mL})$ were analysed in six replicates to evaluate the efficiency of oxyclozanide extraction from the bio-matrix. Recovery was determined by comparing the analytical results of the extracted QC samples with the pure standards without extraction.

Stability was assessed by analysing replicates $(n=6)$ of the QC samples at concentrations of $0.02048 \mu \mathrm{g} / \mathrm{mL}$, $12.7612 \mu \mathrm{g} / \mathrm{mL}$ and $25.600 \mu \mathrm{g} / \mathrm{mL}$ under various the sample storage and processing procedure [27]: (1) the plasma samples were kept at ambient temperature for $24 \mathrm{~h}$; (2) the plasma samples were stored at $-20^{\circ} \mathrm{C}$ for 60 days; (3) the plasma samples were kept in the autosampler at $4{ }^{\circ} \mathrm{C}$ for $24 \mathrm{~h}$; (4) the plasma samples were determined after three freeze-thaw cycles $\left(25^{\circ} \mathrm{C}\right.$ to $\left.-20^{\circ} \mathrm{C}\right)$ [25].

\section{Pharmacokinetic study}

Eight healthy breeding age Simmental cattle of both sexes aged between 1.5 and 3 years and with a mean body weight $(\mathrm{BW})$ of $317 \pm 24.46 \mathrm{~kg}$ were obtained from a commercial company (Wanhe Livestock Industry Technology Development Co., Ltd., Gansu, China) and acclimated to a standard environmentally controlled animal room (temperature, $25 \pm 2{ }^{\circ} \mathrm{C}$; relative humidity of $50 \%$ and a $12: 12 \mathrm{~h}$ light/dark cycle) for 1 week before 


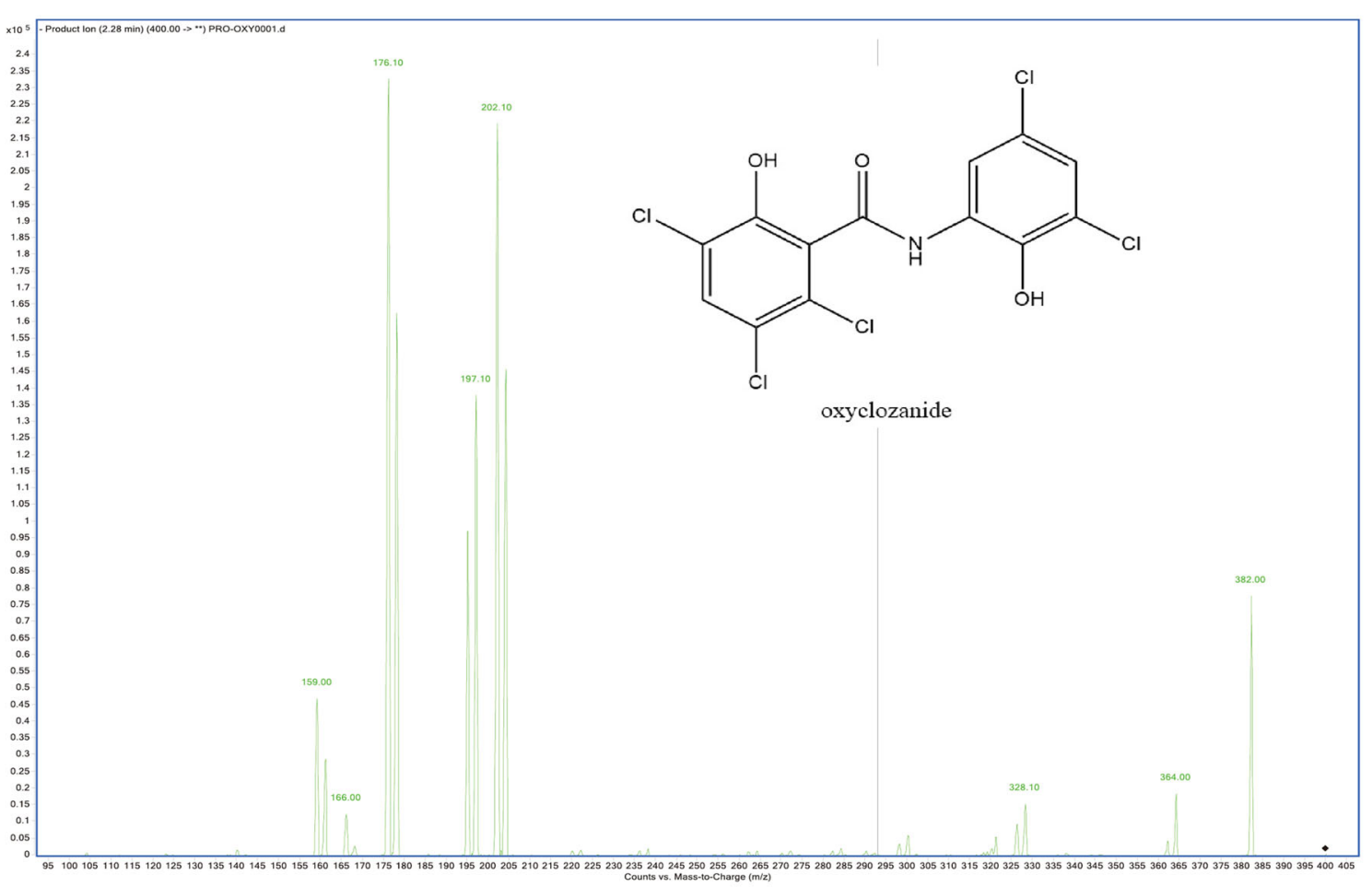

A

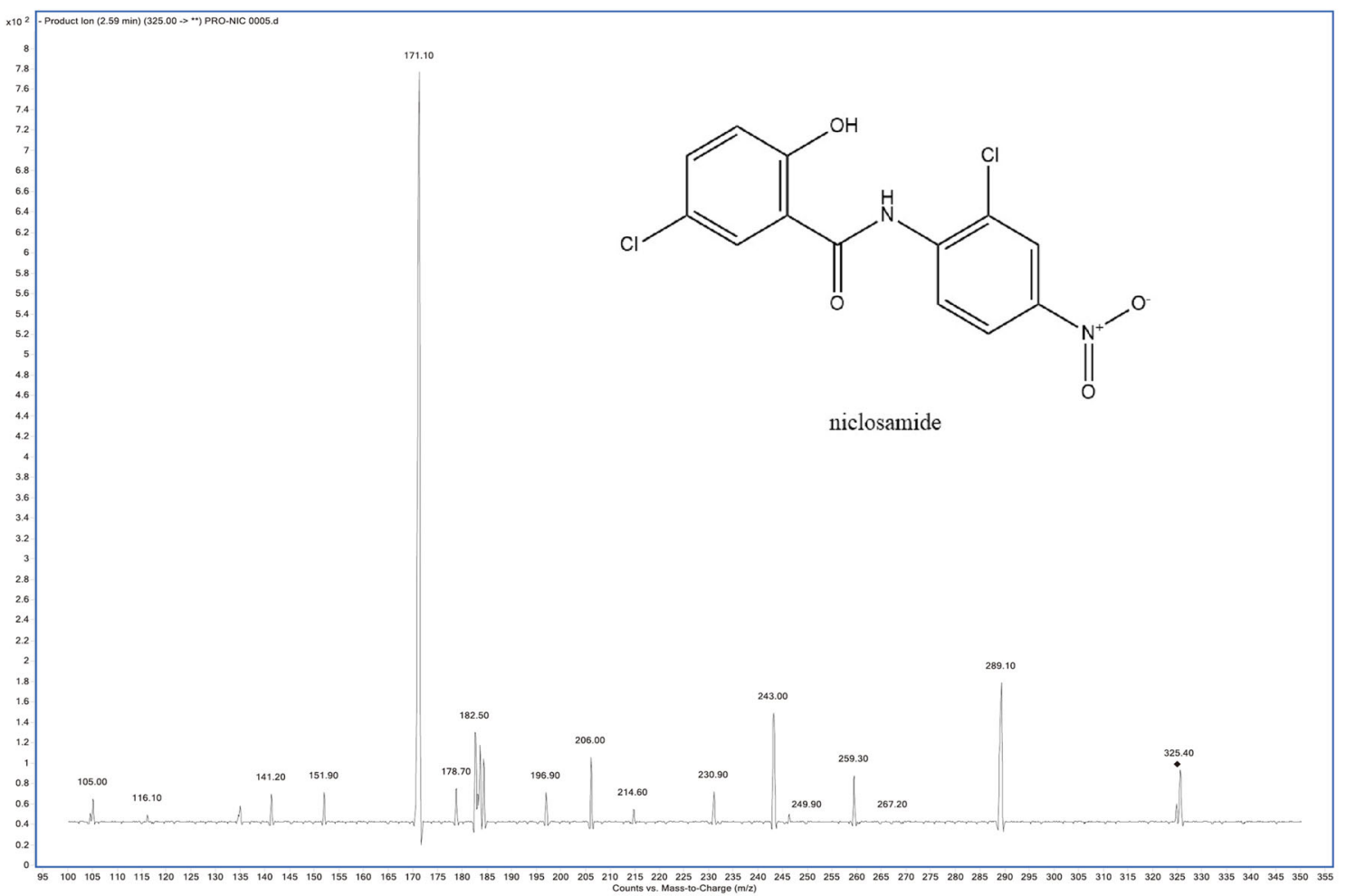

Fig. 1 Full-scan product ion spectra of $[\mathrm{M}-\mathrm{H}]^{-}$ions for oxyclozanide (a) and IS (b) 


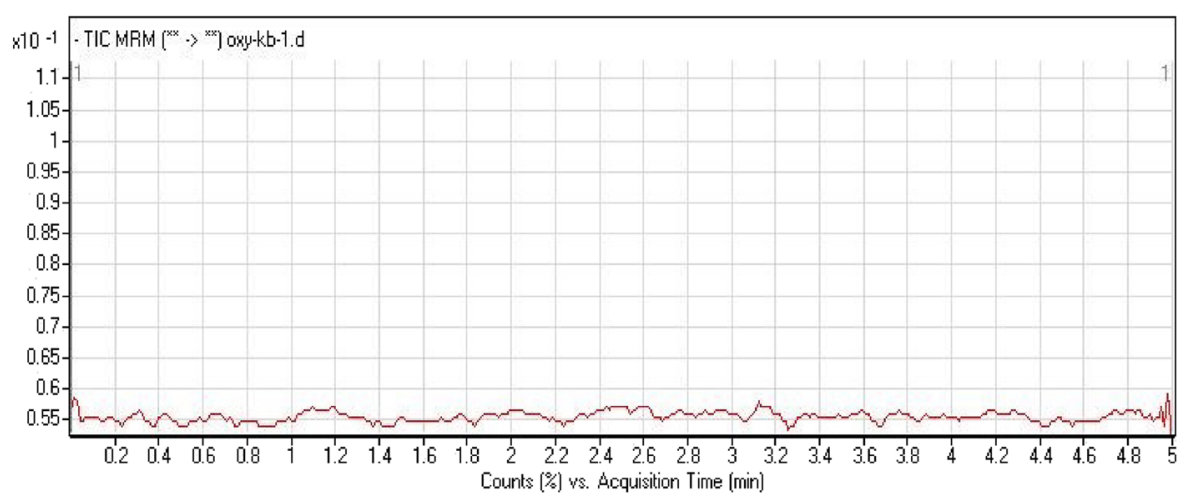

A

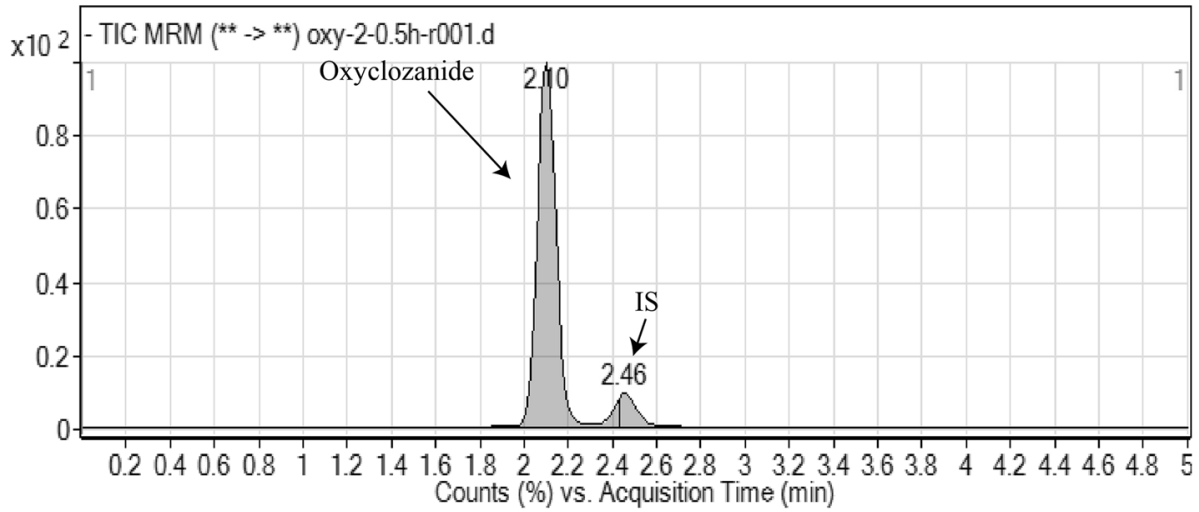

B

Fig. 2 Chromatograms of plasma from cattle. Blank (a), oxyclozanide (b, left panel) and IS (b, right panel)

the experiment. Animals were orally administered oxyclozanide once, and the dose was based on live weight. All experimental procedures were approved and performed in accordance with the Guidelines for the Care and Use of Laboratory Animals of the Lanzhou Institute of Animal Science and Veterinary Pharmaceutics (number: SCXK (Gan) 2014-0002). All cattle were maintained under nearly identical conditions, and adequate water and rations were provided.

The animals received an oral suspension of oxyclozanide at a dose of $10 \mathrm{mg} / \mathrm{kg}$ BW. Blood samples (5 $\mathrm{mL}$ ) were collected by jugular venepuncture at $0 \mathrm{~h}$, 0.5 h, 1 h, 4 h, 8 h, 12 h, 16 h, 18 h, 20 h, 24 h, 28 h, 36 h, $48 \mathrm{~h}, 72 \mathrm{~h}, 96 \mathrm{~h}, 120 \mathrm{~h}, 168 \mathrm{~h}$ and $216 \mathrm{~h}$. After all the blood samples were centrifuged at $3000 \mathrm{rpm}$ for 10 min, plasma samples were collected and immediately stored in a $-20^{\circ} \mathrm{C}$ freezer until analysis using LC-MS/ MS. All the animals were alive and healthy after the experiment.

Pharmacokinetic parameters were calculated using WinNonlin Professional software version 5.2 (Pharsight, Mountain View, CA, USA). The best pharmacokinetic model was confirmed according to the minimum Akaike
Information Criterion (AIC) value principle and utilized for data fitting and parameter estimation [28]. Plasma area under the curve (AUC), plasma clearance rate (CL/ F), peak plasma concentration $\left(\mathrm{C}_{\max }\right)$, half-life $\left(\mathrm{T}_{1 / 2}\right)$, and peak time $\left(\mathrm{T}_{\max }\right)$ are presented as means $\pm \mathrm{SD}$.

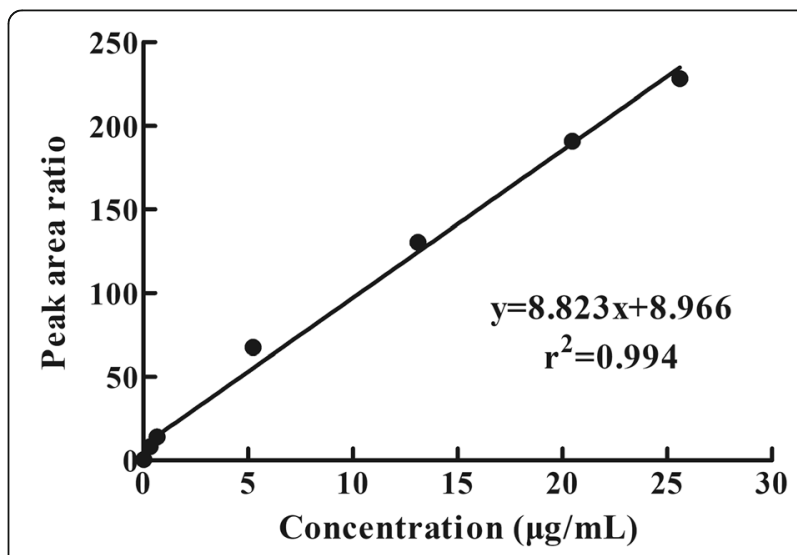

Fig. 3 Calibration curve 
Table 1 Intra- and inter-day precision and accuracy of oxyclozanide in cattle plasma

\begin{tabular}{|c|c|c|c|c|}
\hline \multirow{2}{*}{$\begin{array}{l}\text { Concentration }(\mu \mathrm{g} / \\
\mathrm{mL})\end{array}$} & \multicolumn{2}{|c|}{ Intra-day precision and accuracy $(n=6)$} & \multicolumn{2}{|c|}{ Inter-day precision and accuracy $(n=18)$} \\
\hline & Accuracy (\%) \pm SD & RSD (\%) & Accuracy (\%) \pm SD & RSD (\%) \\
\hline 0.020 & $112.8 \pm 5.7$ & 5.1 & $109.5 \pm 4.6$ & 4.2 \\
\hline 0.02048 & $126.7 \pm 4.2$ & 3.3 & $123.6 \pm 3.7$ & 3.0 \\
\hline 12.7612 & $105.0 \pm 0.2$ & 0.2 & $105.4 \pm 0.9$ & 0.9 \\
\hline 25.600 & $97.2 \pm 0.3$ & 0.3 & $97.4 \pm 0.5$ & 0.5 \\
\hline
\end{tabular}

\section{Results}

\section{Mass spectrometry and chromatography}

In negative ESI mode, oxyclozanide and the IS exhibited good responses. The full-scan ion spectra indicated that the most abundant ions observed for oxyclozanide were $[\mathrm{M}-\mathrm{H}]^{-}$ions at $\mathrm{m} / \mathrm{z} 401.46$ and $\mathrm{m} / \mathrm{z} 327.12$ for the IS. The quantification of oxyclozanide was carried out with MRM mode for high selectivity and sensitivity of acquisition data. The ion transitions of MRM were selected as $\mathrm{m} / \mathrm{z} 401.46$ to 176.2 for oxyclozanide and $\mathrm{m} / \mathrm{z} 327.12$ to 171.1 for the IS (Fig. 1).

The analysis was conducted with mobile phase A, $0.01 \%$ HOAc in water:MeCN $(90: 10, \mathrm{v} / \mathrm{v})$, and mobile phase B, $5 \mathrm{mM}$ ammonium formate in $\mathrm{MeOH}: \mathrm{MeCN}$ $(75: 25, \mathrm{v} / \mathrm{v})$, at a ratio of $10: 90 \mathrm{v} / \mathrm{v}$ for mobile phases A and B. A $75 \mathrm{~mm}$ column subjected to isocratic elution of the mobile phase for $5 \mathrm{~min}$ at a flow rate of $0.4 \mathrm{~mL} / \mathrm{min}$ was used for chromatographic separation. Under optimized LC and MS conditions, oxyclozanide and the IS were separated with retention times of $2.10 \mathrm{~min}$ and $2.46 \mathrm{~min}$, respectively, and endogenous substances in the plasma did not interfere with analyte detection. Figure 2 shows the chromatograms of untreated plasma and plasma containing oxyclozanide and the IS at $5 \mathrm{~min}$ after oral administration.

\section{Method validation \\ Selectivity and matrix effect}

The specificity of the method was assessed by analysing each blank plasma sample from eight different cattle using the aforementioned chromatographic conditions. None of the samples exhibited endogenous substancemediated interference in the retention time of oxyclozanide or the IS.

In an evaluation of the effect of the plasma matrix on oxyclozanide and IS levels in eight diverse blank cattle plasma samples, the mean matrix effect on oxyclozanide was $96.3 \pm 2.1 \%$, while the matrix effect on the IS was $95.7 \pm 1.6 \%$.

\section{LLOQ and linearity}

The LLOQ and LLOD of oxyclozanide were $0.020 \mu \mathrm{g} /$ $\mathrm{mL}$ and $0.010 \mu \mathrm{g} / \mathrm{mL}$, respectively. The calibration curve for oxyclozanide was linear over the concentration range of $0.02048-25.600 \mu \mathrm{g} / \mathrm{mL}$ according to the results of a weighted $\left(1 / \mathrm{x}^{2}\right)$ least-square linear regression analysis. The calibration curves are shown in Fig. 3. The extrapolated equation of the calibration curve for oxyclozanide was $y=8.823 x+8.966\left(r^{2}=0.994\right)$ for concentrations ranging from $0.02048-25.600 \mu \mathrm{g} / \mathrm{mL}$.

\section{Accuracy and precision}

The results of the analyses of the intra- and inter-day precision and accuracy of the QC samples $(0.02048 \mu \mathrm{g} /$ $\mathrm{mL}, \quad 12.7612 \mu \mathrm{g} / \mathrm{mL}$ and $25.600 \mu \mathrm{g} / \mathrm{mL})$ and LLOD $(0.020 \mu \mathrm{g} / \mathrm{mL})$ samples are presented in Table 1 . The intra-day accuracy ranged from 97.2 to $126.7 \%$, and the inter-day accuracy ranged from 97.4 to $123.6 \%$. The intra- and inter-day precisions were $0.2-5.1 \%$ and $0.5-4.2 \%$, respectively.

\section{Recovery}

Table 2 displays the recovery of oxyclozanide and IS extracted from the plasma matrix. The mean extraction recoveries of oxyclozanide at QC concentrations of $0.02048 \mu \mathrm{g} / \mathrm{mL}, 12.7612 \mu \mathrm{g} / \mathrm{mL}$ and $25.600 \mu \mathrm{g} / \mathrm{mL}$ were $100.8 \pm 3.2 \%, 106.0 \pm 0.8 \%$, and $98.1 \pm 1.9 \%$, respectively. The mean extraction recovery of the IS was $98.2 \pm 1.7 \%$.

\section{Stability}

The results of stability for oxyclozanide under different storage conditions was shown in Table 3. The accuracy was $90.8-102.2 \%$ and precision (RSD\%) was $1.7-3.1 \%$, indicating that oxyclozanide was fairly stable under all experimental conditions.

Table 2 Recovery of oxyclozanide $(n=6)$ from cattle plasma

\begin{tabular}{lll}
\hline $\begin{array}{l}\text { Concentration } \\
(\mu \mathrm{g} / \mathrm{mL})\end{array}$ & Recovery $(\%, n=6)$ & \\
\cline { 2 - 3 } Oxyclozanide & Mean $(\%) \pm \mathrm{SD}$ & \\
0.02048 & $100.8 \pm 3.2$ & 3.2 \\
12.7612 & $106.0 \pm 0.8$ & 0.8 \\
25.600 & $98.1 \pm 1.9$ & 2.2 \\
IS & & \\
0.004 & $98.2 \pm 1.7$ & 1.7 \\
\hline
\end{tabular}


Table 3 Stability of oxyclozanide in cattle plasma samples under various conditions $(n=6)$

\begin{tabular}{llll}
\hline Storage conditions & $\begin{array}{l}\text { Concentration } \\
(\mu \mathrm{g} / \mathrm{mL})\end{array}$ & $\begin{array}{l}\text { Accuracy } \\
\pm \mathrm{SD}(\%)\end{array}$ & $\begin{array}{l}\text { RSD } \\
(\%)\end{array}$ \\
\hline Ambient temperature for $24 \mathrm{~h}$ & 0.02048 & $100.5 \pm 2.1$ & 2.1 \\
& 12.7612 & $98.2 \pm 1.7$ & 1.7 \\
& 25.600 & $102.2 \pm 2.3$ & 2.3 \\
At $-20^{\circ} \mathrm{C}$ for 60 days & 0.02048 & $94.5 \pm 2.2$ & 2.3 \\
& 12.7612 & $95.1 \pm 2.8$ & 2.9 \\
& 25.600 & $98.9 \pm 1.9$ & 1.9 \\
At $4{ }^{\circ} \mathrm{C}$ in the autosampler & 0.02048 & $96.6 \pm 2.5$ & 2.5 \\
for $24 \mathrm{~h}$ & 12.7612 & $101.4 \pm 1.5$ & 2.6 \\
& 25.600 & $98.4 \pm 2.7$ & 2.1 \\
3 freeze-thaw cycles & 0.02048 & $90.8 \pm 2.7$ & 3.0 \\
& 12.7612 & $94.6 \pm 2.5$ & 2.6 \\
& 25.600 & $96.2 \pm 3.0$ & 3.1 \\
\hline
\end{tabular}

\section{Pharmacokinetic studies}

The well-validated method described above was successfully applied to quantify oxyclozanide levels in plasma samples after the oral administration of an oxyclozanide suspension to cattle at a dose of $10 \mathrm{mg} / \mathrm{kg}$. The plasma concentration-time curves for oxyclozanide were adequately fitted using a one-compartment model. The mean plasma concentration vs. time curves for oxyclozanide are shown in Fig. 4. The major pharmacokinetic parameters of oxyclozanide are presented in Table 4 . The $\mathrm{C}_{\max }, \mathrm{T}_{\max }$ and $\mathrm{T}_{1 / 2}$ of oxyclozanide were $15.870 \pm 2.855 \mu \mathrm{g} / \mathrm{mL}, 22.032 \pm$ $3.343 \mathrm{~h}$, and $64.40 \pm 30.18 \mathrm{~h}$, respectively. The $\mathrm{AUC}_{(0-\infty)}$ for oxyclozanide was $965.608 \pm 220.097 \mathrm{~h} * \mathrm{\mu g} / \mathrm{mL}$.

\section{Discussion}

Full ESI scans were performed in both ESI $( \pm)$ detection modes to optimize the mass spectrometry parameters for oxyclozanide and the IS. Better MS responses were achieved in ESI (-) mode compared with ESI (+) mode, consistent with previous reports $[16,18,19]$. The choice of the IS is particularly important, as it provides a baseline value for the continuous monitoring of the performance of the chromatograph and mass spectrometer during analysis, and affects the precision and accuracy of the method [29, 30]. Niclosamide is a proper IS due to its structural and chemical similarity to the analyte, its similar retention behaviour to the analyte, as well as be well resolved from the analyte and other peaks. The composition of the mobile phase used in our study was described in previous studies $[16,19,20]$. However, the chromatographic conditions were simplified in our study, and the suitable ratio of the mobile phase was adjusted with equal degrees of elution. Under this chromatographic condition, the retention times were $2.10 \mathrm{~min}$ for oxyclozanide and $2.46 \mathrm{~min}$ for niclosamide. Retention times and the running time were shorter than in previously published reports $[16,19,20]$. Acetic acid increased the ionization of all tested compounds, whereas the addition of ammonium acetate resulted in higher sensitivity [24]. This composition was deemed suitable for the separation and ionization of oxyclozanide and the IS with good peak shapes and resolution.

In the validation study, the LC-MS/MS method was validated in terms of selectivity, linearity, matrix effect, LLOQ, recovery, accuracy and precision and stability. These variables were assessed according to guidelines established by the US Food and Drug Administration for bioanalytical method validation [31]. A good linear relationship between the ratio of the oxyclozanide concentration and quantitative ion peak area was established. The intra- and inter-day precision and accuracy data were within the acceptable limits, indicating that the method developed in the present study was reliable and reproducible in terms of the quantitative analysis of oxyclozanide levels in cattle plasma. In addition, liquidliquid extraction with acetonitrile was simple and more efficient than the method described in a previous report [22], and no endogenous substance-mediated interference was observed for the retention time of oxyclozanide or the IS. Furthermore, oxyclozanide was stable in cattle plasma after exposure of the plasma samples to different storage conditions. Thus, a simple and sensitive

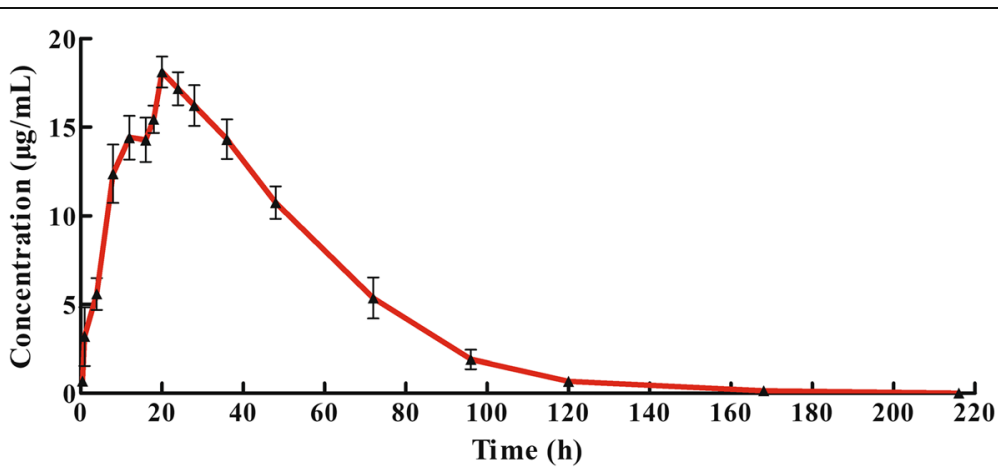

Fig. 4 Mean plasma concentration-time profile after the oral administration of $10 \mathrm{mg} / \mathrm{kg}$ oxyclozanide to cattle $(n=8)$ 
Table 4 The pharmacokinetic parameters (mean \pm SD) of oxyclozanide in cattle following oral administration at a dose of $10 \mathrm{mg} / \mathrm{kg}(n=8)$

\begin{tabular}{ll}
\hline Parameters & Mean $\pm S D$ \\
\hline$A \cup C_{(0-\infty)}\left(h^{*} \mu \mathrm{g} / \mathrm{mL}\right)$ & $965.608 \pm 220.097$ \\
$\mathrm{AUC} C_{(0-\mathrm{t})}\left(h^{*} \mu \mathrm{g} / \mathrm{mL}\right)$ & $916.534 \pm 202.121$ \\
$\mathrm{~K} 01 \_\mathrm{HL}(\mathrm{h})$ & $14.706 \pm 2.509$ \\
$\mathrm{~K} 10 \_H L(h)$ & $14.938 \pm 2.650$ \\
$\mathrm{CL} / \mathrm{F}(\mathrm{mL} / \mathrm{h} / \mathrm{kg})$ & $11.426 \pm 2.442$ \\
$\mathrm{~T}_{\max }(\mathrm{h})$ & $22.032 \pm 3.343$ \\
$\mathrm{~T}_{1 / 2}(\mathrm{~h})$ & $64.40 \pm 30.18$ \\
$\mathrm{C}_{\max }(\mu \mathrm{g} / \mathrm{mL})$ & $15.870 \pm 2.855$ \\
\hline
\end{tabular}

LC-MS/MS method has been developed and validated in our study.

The pharmacokinetics of oxyclozanide in cattle were assessed using the LC-MS/MS method and the pharmacokinetic properties were obtained in this study. A previously published study reported the pharmacokinetics of oxyclozanide in sheep and goats following the administration of a single oral dose [22]. The $\mathrm{T}_{1 / 2}$ were $21.74 \mathrm{~h}$ for sheep and $18.71 \mathrm{~h}$ for goats, the $\mathrm{AUC}_{(0-\infty)}$ values in sheep and goats were $488.70 \mu \mathrm{g} . \mathrm{h} / \mathrm{mL}$ and $309.33 \mu \mathrm{g} . \mathrm{h} /$ $\mathrm{mL}$, respectively, and the $\mathrm{C}_{\max }$ in sheep and goats were $11.01 \mu \mathrm{g} / \mathrm{mL}$ and $6.68 \mu \mathrm{g} / \mathrm{mL}$, respectively. However, the $\mathrm{T}_{1 / 2}$ of oxyclozanide in cattle plasma reported here was $64.40 \mathrm{~h}$, which is a much longer time than the period in sheep and goats. The $\mathrm{AUC}_{(0-\infty)}(965.608 \mathrm{~h} / \mu \mathrm{g} / \mathrm{mL})$ of oxyclozanide in cattle is larger than in sheep and goats, and the $C_{\max }(15.87 \mu \mathrm{g} / \mathrm{mL})$ of oxyclozanide is higher than in sheep and goats. The reasons for these differences may be due to the differences in animal species, the selectivity of the analytical methods or the formulation and preparation techniques. However, following the oral administration of an oxyclozanide suspension, the drug is slowly eliminated from cattle plasma, and this property may contribute to the therapeutic effect in vivo. To our knowledge, this study is the first to report the pharmacokinetics of oxyclozanide in cattle, and our results will provide a basis for further research on the administration of oxyclozanide suspensions in animals.

\section{Conclusions}

A simple and sensitive LC-MS/MS method has been completely validated, displayed excellent sensitivity, linearity, precision and accuracy, and was successfully applied to an evaluation of the pharmacokinetics of oxyclozanide in cattle plasma after oral administration. This study is the first to report the pharmacokinetic parameters of oxyclozanide in cattle and will be useful for further evaluations of the pharmacokinetic properties of oxyclozanide or for the monitoring of therapeutic drugs in animals.

\section{Abbreviations}

AUC: An average area under the curve; BW: Body weight; $C_{\text {max }}$ : Peak plasma concentration; CL/F: Plasma clearance rate; ESI: Electrospray ionization; F. hepatica: Fasciola hepatica; HOAc: Acetic acid; HPLC-MS/MS: Highperformance liquid chromatography-tandem mass spectrometry; IS: Internal standard; LC-MS/MS: Liquid chromatography coupled with tandem mass spectrometry; LLOD: Lower limit of detection; LLOQ: The lower limit of quantification; MeCN: Acetonitrile; $\mathrm{MeOH}$ : Methanol; MRM: Multiple reaction monitoring; QC: Quality control; RSD: The relative standard deviation; T max: Peak time; $T_{1 / 2}$ : Half-life; UPLC-MS/MS: Ultra-high-performance liquid chromatography-tandem mass spectrometry

Acknowledgments

Not applicable

Declarations

All authors declare the absence of any financial or personal interests that could inappropriately influence the current study. The final article has been approved by all authors.

\section{Authors' contributions}

$\mathrm{YB}, \mathrm{XZ}$ and $\mathrm{BL}$ participated in the animal experiments. HS revised the manuscript. JiliZ supervised the experiments and wrote the manuscript. JiyuZ designed the study and critically revised the manuscript. All authors read and approved the final manuscript.

\section{Funding}

This study was supported by grants from the Key Project in the National Science \& Technology Pillar Program during the Twelfth Five-year Plan Period (2015BAD11B01) and by the earmarked fund for the China Agriculture Research System (CARS-37). The funding organization had no role in the design of the study and collection, analysis, and interpretation of data and in writing the manuscript.

\section{Availability of data and materials}

All data generated or analysed during this study are available from the corresponding author on reasonable request.

\section{Ethics approval and consent to participate}

The study executed by Dr. Jili Zhang and Dr. Jiyu Zhang was conducted between February and May 2017 in Lanzhou Institute of Husbandry and Pharmaceutical Sciences of Lanzhou, Gansu Province, China. Eight cattle were used in this study. All experimental methods, animal care and the barn environment of this study strictly complied with the Guide for the Care and Use of Laboratory Animals, Lanzhou Institute of Husbandry and Pharmaceutical Sciences, China. In addition, all efforts were made to minimize suffering. Thus, we agreed to conduct the experiment, and the certificate number was SCXK (Gan) 2014-0002.

\section{Consent for publication}

Not applicable

\section{Competing interests}

The authors declare that they have no competing interests.

\section{Author details}

${ }^{1}$ Key Laboratory of Veterinary Pharmaceutical Development, Lanzhou Institute of Husbandry and Pharmaceutical Sciences, Chinese Academy of Agricultural Sciences, Ministry of Agriculture, Lanzhou, Gansu Province 730050, People's Republic of China. ${ }^{2}$ Key Laboratory of New Animal Drug Project of Gansu Province, Lanzhou, Gansu Province, People's Republic of China. ${ }^{3}$ Lanzhou Institute of Husbandry and Pharmaceutical Sciences, Chinese Academy of Agricultural Sciences, Lanzhou, Gansu Province, People's Republic of China. 
Received: 21 November 2018 Accepted: 16 June 2019

Published online: 24 June 2019

\section{References}

1. Cwiklinski K, O'Neill SM, Donnelly S, Dalton JP. A prospective view of animal and human Fasciolosis. Parasite Immunol. 2016;38:558-68 https://doi.org/10. 1111/pim.12343.

2. Morphew RM, Eccleston N, Wilkinson TJ, McGarry J, Perally S, Prescott M, Ward D, Williams D, Paterson S, Raman M, Ravikumar G, Saifullah MK, Abid SMA, McVeigh P, Maule AG, Brophy PM, LaCourse EJ. Proteomics and in silico approaches to extend understanding of the glutathione transferase superfamily of the tropical liver fluke Fasciola gigantica. J Proteome Res. 2012;11:5876-89 https://doi.org/10.1021/pr300654w.

3. Piedrafita D, Spithill TW, Smith RE, Raadsma HW. Improving animal and human health through understanding liver fluke immunology. Parasite Immunol. 2010;32:572-81 https://doi.org/10.1111/j.1365-3024. 2010.01223.x.

4. Mas-Coma S, Bargues MD, Valero MA. Fascioliasis and other plant-borne trematode zoonoses. Int J Parasitol. 2005:35:1255-78 https://doi.org/10. 1016/j.jpara.2005.07.010

5. Mehmood K, Zhang H, Sabir AJ, Abbas RZ, ljaz M, Durrani AZ, Saleem MH, Ur Rehman M, lqbal MK, Wang Y, Ahmad Hl, Abbas T, Hussain R, Ghori MT, Ali S, Khan AU, Li J. A review on epidemiology, global prevalence and economical losses of fasciolosis in ruminants. Microb Pathog. 2017;109: 253-62 https://doi.org/10.1016/j.micpath.2017.06.006.

6. Elliott TP, Kelley JM, Rawlin G, Spithill TW. High prevalence of fasciolosis and evaluation of drug efficacy against Fasciola hepatica in dairy cattle in the Maffra and Bairnsdale districts of Gippsland, Victoria, Australia. Vet Parasitol. 2015;209:117-24 https://doi.org/10.1016/j.vetpar.2015.02.014.

7. Olaechea F, Lovera V, Larroza M, Raffo F, Cabrera R. Resistance of fasciola hepatica against triclabendazole in cattle in Patagonia (Argentina). Vet Parasitol. 2011;178:364-6 https://doi.org/10.1016/j.vetpar. 2010.12.047.

8. Coles GC, Stafford KA. Activity of oxyclozanide, nitroxynil, clorsulon and albendazole against adult triclabendazole-resistant Fasciola hepatica. Vet Rec. 2001;148:723-4.

9. Walley JK. Oxyclozanide (3,3',5,5',6-pentachloro-2,2'-dihydroxybenzanilide-6Zanil") in the treatment of the liver fluke Fasciola hepatica in sheep and cattle. Vet Rec. 1966;78:267-76.

10. Paraud C, Fournier E, Robergeot V, Kulo A, Pors I, Baudry C, Chartier C. Calicophoron daubneyi infection in grazing goats: results from a crosssectional coprological survey in France. Small Rumin Res. 2009;82:66-8 https://doi.org/10.1016/j.smallrumres.2009.01.009.

11. Paraud C, Gaudin C, Pors I, Chartier C. Efficacy of oxyclozanide against the rumen fluke Calicophoron daubneyi in experimentally infected goats. Vet J. 2009;180:265-7 https://doi.org/10.1016/j.tvjl.2008.01.002.

12. Rolfe PF, Boray JC. Chemotherapy of paramphistomosis in cattle. Aust Vet J. 1987:64:328-32.

13. Shokier KM, Aboelhadid SM, Waleed MA. Efficacy of five anthelmintics against a natural Fasciola species infection in cattle. Beni-Suef Univ J Basic Appl Sci. 2013;2:41-5 https://doi.org/10.1016/j.bjbas.2013.09.006.

14. Coles GC, Stafford KA. Activity of oxyclozanide, nitroxynil, clorsulon and albendazole against adult triclabendazole-resistant Fasciola hepatica. Vet Rec J Br Vet Assoc. 2001;23:723-4.

15. Zhang JL, Si HF, Zhou XZ, Shang XF, Li B, Zhang JY. High prevalence of fasciolosis and evaluation of the efficacy of anthelmintics against Fasciola hepatica in buffaloes in Guangxi, China. Int J Parasitol Parasites Wildl. 2019;8: 82-7.

16. Whelan M, Kinsella B, Furey A, Moloney M, Cantwell H, Lehotay SJ, Danaher M. Determination of anthelmintic drug residues in milk using ultra high performance liquid chromatography-tandem mass spectrometry with rapid polarity switching. J Chromatogr A. 2010;1217:4612-22 https://doi.org/10. 1016/j.chroma.2010.05.007

17. Whelan M, Chirollo C, Furey A, Cortesi ML, Anastasio A, Danaher M. Investigation of the persistence of levamisole and oxyclozanide in milk and fate in cheese. J Agric Food Chem. 2010;58:12204-9 https://doi.org/ $10.1021 / j f 102725 b$

18. Sakamoto M, Takeba K, Sasamoto T, Kusano T, Hayashi H, Kanai S, Kanda M, Nagayama T. Determination of bithionol, bromophen, nitroxynil, oxyclozanide, and tribromsalan in milk with liquid chromatography coupled with tandem mass spectrometry. J AOAC Int. 2010;93:1340-6.
19. Cooper KM, Whelan M, Danaher M, Kennedy DG. Stability during cooking of anthelmintic veterinary drug residues in beef. Food Addit Contam Part A Chem Anal Control Expo Risk Assess. 2011;28:155-65.

20. Caldow M, Sharman M, Kelly M, Day J, Hird S, Tarbin JA. Multi-residue determination of phenolic and salicylanilide anthelmintics and related compounds in bovine kidney by liquid chromatography-tandem mass spectrometry. J Chromatogr A. 2009;1216:8200-5 https://doi.org/10.1016/j. chroma.2009.04.008.

21. Khan AR, Akhtar MJ, Mahmood R, Ahmed SM, Malook S, lqbal M. LC assay method for oxfendazole and oxyclozanide in pharmaceutical preparation. J Pharm Biomed Anal. 2000;22:111-4.

22. Gokbulut C, Yalinkilinc HS, Aksit D, Veneziano V. Comparative pharmacokinetics of levamisole-oxyclozanide combination in sheep and goats following per os administration. Can J Vet Res. 2014;78:316-20.

23. Kadi AA, Alrabiah H, Attwa MW, Attia S, Mostafa GAE. Development and validation of HPLC-MS/MS method for the determination of lixivaptan in mouse plasma and its application in a pharmacokinetic study. Biomed Chromatogr. 2017;31 https://doi.org/10.1002/bmc.4007.

24. Liu SJ, Zhou L, Zhang J, Yu BY, Li CY, Liu ZX, Ju WZ. Determination of limonin in dog plasma by liquid chromatography-tandem mass spectrometry and its application to a pharmacokinetic study. Biomed Chromatogr. 2013;27:515-9 https://doi.org/10.1002/bmc.2821.

25. Li B, Gong SY, Zhou XZ, Yang YJ, Li JY, Wei XJ, Cheng FS, Niu JR, Liu XW, Zhang JY. Determination of antibacterial agent tilmicosin in pig plasma by LC/MS/MS and its application to pharmacokinetics. Biomed Chromatogr. 2017;31 https://doi.org/10.1002/bmc.3825.

26. ICH (2005). Guidelines: validation of analytical procedures: text and methodology, Q2 (R1).

27. Chen Q, Li P, Zhang J, Zhu J. Preclinical pharmacokinetic analysis of armillarisin succinate ester in mouse plasma and tissues by LC-MS/MS Biomed Chromatogr. 2013;27:130-6. https://doi.org/10.1002/bmc.2762.

28. Klinkenberg D, Tobias TJ, Bouma A, van Leengoed LAMG, Stegeman JA. Simulation study of the mechanisms underlying outbreaks of clinical disease caused by Actinobacillus pleuropneumoniae in finishing pigs. Vet J. 2014:202:99-105.

29. Mcllhenny EH, Pipkin KE, Standish L, Wechkin HA, Strassman R, Barker SA. J Chromatogr A. 2009;1216:8960.

30. Tarcomnicu I, Gheorghe MC, Silvestro L, Savu SR, Boaru I, Tudoroniu A. J Chromatogr B. 2009;877:3159.

31. US Food and Drug Administration. Guidance for industry: bioanalytical method validation. Rockville: US Department of Health and Human Services, Food and Drug Administration, Center for Drug Evaluation and Research and Center for Veterinary Medicine; 2013.

\section{Publisher's Note}

Springer Nature remains neutral with regard to jurisdictional claims in published maps and institutional affiliations.

Ready to submit your research? Choose BMC and benefit from:

- fast, convenient online submission

- thorough peer review by experienced researchers in your field

- rapid publication on acceptance

- support for research data, including large and complex data types

- gold Open Access which fosters wider collaboration and increased citations

- maximum visibility for your research: over $100 \mathrm{M}$ website views per year

At BMC, research is always in progress.

Learn more biomedcentral.com/submissions 